\title{
Crude oil-utilizing strain Desulfovibrio vulgaris D107G3, a mesophilic sulfate-reducing bacterium isolated from Bach Ho gas-oil field in Vung Tau, Vietnam
}

\author{
Vi khuẩn khử sunphat ưa ấm có khả năng sử dụng dầu thô Desulfovibrio vulgaris D107G3 \\ phân lập từ giếng khoan dầu khí mỏ Bạch Hổ, vũng Tàu, Việt Nam
}

\author{
NGUYEN, Thi Thu Huyen ${ }^{1 *}$; TRAN, Thi Kim Thoa²; LAI, Thuy Hien² \\ ${ }^{1}$ Faculty of Biotechnology, Ho Chi Minh city University of Food Industry, 140 Le Trong Tan, Tan Phu district, Ho Chi Minh city, Vietnam; ${ }^{2}$ Institute \\ of Biotechnology, Vietnam Academy of Science and Technology, 18 Hoang Quoc Viet, Cau Giay district, Hanoi, Vietnam
}

\begin{abstract}
Some of anaerobic, mesophilic sulfate-reducing bacteria that produce $\mathrm{H}_{2} \mathrm{~S}$ and cause microbial metal corrosion can degrade crude oil in anaerobic conditions. In this study, a mesophilic sulfate-reducing bacterial strain D107G3 isolated from Bach Ho gas-oil field in Vung Tau, Vietnam that is able to utilize crude oil in the anaerobic condition is reported. The strain D107G3 was classified as a Gram-negative bacterium by using Gram staining method. Basing on scanning microscopy observation, the cell of a strain D107G3 had a curved rod shape. The 16S rRNA gene sequence analysis showed that the strain D107G3 was identified as Desulfovibrio vulgaris with 99.7\% identity. The suitable conditions for its growth that was determined via estimating its $\mathrm{H}_{2} \mathrm{~S}$ production was the modified Postgate B medium containing $1 \%(\mathrm{~V} / \mathrm{V})$ crude oil, $1 \% \mathrm{NaCl}(\mathrm{W} / \mathrm{V}), \mathrm{pH} 7$ and $30^{\circ} \mathrm{C}$ incubation. In these conditions, the strain D107G3 can consume $11.4 \%$ of crude oil total and oxidize heavy crude oil ( $\geq$ C45) for one month at anoxic condition. These obtained results not only contribute to the science but also continue to warn about the dangers of mesophilic sulfate reducing bacteria to the process of crude oil exploitation, use, and storage in Vung Tau, Vietnam.
\end{abstract}

\begin{abstract}
Trong bài báo này, chủng vi khuẩn khử sunphat (KSF) ưa ấm D107G3 phân lập từ giếng khoan dầu khí mỏ Bạch Hổ, Vũng Tàu, Việt Nam có khả năng sử dụng dầu thô trong điều kiện kị khí được công bố. Chủng D107G3 được xác định là vi khuẩn Gram âm nhờ phương pháp nhuộm Gram. Quan sát trên kính hiển vi điện tử quét cho thấy tế bào chủng D107G3 có hình que cong. Kết quả phân tích trình tự gen 16S rRNA đã xác định được chủng D107G3 thuộc loài Desulfovibrio vulgaris với độ tương đồng 99.7\%. Thông qua đánh giá lượng $\mathrm{H}_{2} \mathrm{~S}$ tạo thành đã khám phá được điều kiện thich hợp cho sinh trưởng của chủng D107G3: môi trường Postgate B cải tiến chứa 1\% (V/V) dầu thô, 1 \% NaCl $\left(g L^{-1}\right)$, pH 7 và nuôi cấy ở $30^{\circ} \mathrm{C}$. Trong điều kiện đó, chủng D107G3 đã sử dụng được 11.4 \% hàm lượng dầu tổng số, thành phần dầu bi phân huỷ là các n-parafin có mach C $\geq 45$ sau 1 tháng nuôi cấy ky. khí. Các kết quả này đóng góp về mặt khoa học và tiếp tục cảnh báo mối nguy hại của KSF ưa ấm đến việc khai thác, sử dụng và bảo quản dầu mỏ ở Vũng Tàu, Việt Nam.
\end{abstract}

Keywords: mesophilic sulfate-reducing bacteria; D107G3; Bach Ho; crude oil utilization; Desulfovibrio vulgaris

\section{Introduction}

Sulfate-reducing bacteria (SRB) are a group of anaerobic bacteria that use sulfates as the terminal electron acceptor in the oxidation of organic compounds. They are found in anaerobic environments such as mud from the bottom of ponds, lakes, marine sediments, etc., and are capable of reducing sulfates to sulphides (Muyzer, Stam, 2008). SRB cause serious problems in industry, especially the offshore oil industry. Many SRB species have been found in oil fields. Moreover, their growths acidified the petroleum formation by producing $\mathrm{H}_{2} \mathrm{~S}$ gas causing reservoir souring. $\mathrm{H}_{2} \mathrm{~S}$ gas generated by SRB is toxic, causing high corrosion leading to corrosion of metal equipment (Muyzer, Stam, 2008;
Enning, Garrelfs, 2014; Basafa, Hawboldt, 2019). This has seriously affected the economic, health, safety and technical issues of the oil and gas exploitation. SRB often use two preferred substrate sources such as lactate and acetate for their growth. Recent studies have shown that many SRB species are capable of degrading hydrocarbons (Al-Asadi, 2011; Suárez-Suárez et al., 2011; Jakel et al., 2015; Rabus et al., 2016; Roy et al., 2018).

In Vietnam, the offshore oil and gas industry in Vung Tau province is also facing the petrochemical acidification and corrosion of metal equipment caused by SRB, including the mesophilic SRB. During the oil and gas exploitation, a large amount of deoxygenated seawater is often pumped into oil wells to maintain pressure in the well and increases the 
secondary oil exploitation. The anaerobic conditions associated with sulfate present in seawater promoted the growth of mesophilic SRB in drilled wells for exploitation and storage systems (Lai et al., 2000). Not only that, some of mesophilic SRB had the ability to utilize crude oil as the substrate source (Nguyen et al, 2010). Thus, in addition to the benefits gained from secondary extraction through water injection method, the risk of losses caused by mesophilic SRB should also be considered. The knowledge of their physiology could help to find out the solution for eliminating them. Thus, in this study, the classification as well as the suitable conditions for growth of an anaerobic, mesophilic sulfate reducing bacterium Desulfovibrio vulgaris D107G3 isolated from Bach Ho gas-oil field in Vung Tau was triggered out.

\section{Materials and methods}

\subsection{Sample}

The mesophilic sulfate reducing bacterial strain D107G3 was isolated from well No. 3 (the secondary oil exploitation well by pumping seawater from outside) at Bachho field in vung Tau (Nguyen et al., 2010).

\subsection{Medium and culture conditions}

The medium used to pre-culture strain D107G3 was modified Postgate B medium containing 1\% NaCl (Lai et al, 2003). The medium used for the isolation and investigation of crude oil utilization of a strain D107G3 was the modified Postgate B medium containing $1 \% \mathrm{NaCl}$ in which lactate and acetate were replaced by crude oil as a sole substrate and yeast extract also was removed from medium components. The medium for cell harvest for total DNA extraction is the Postgate $\mathrm{C}$ medium with the added $\mathrm{FeSO}_{4}$ content of $0.004 \mathrm{gL}^{-1}$ (Nguyen et al, 2011). For solid medium, $12 \mathrm{gL}^{-1}$ agar was added to the medium. In all experiments (isolation, Gram determination, cell morphology observation, cell harvest for DNA extraction, effect of environmental factors, total oil content analysis), the strains D107G3 were all cultivated under anaerobic conditions at $30^{\circ} \mathrm{C}$ (except for the experiment of temperature effect) with $1 \%$ of the preculture of strain D107G3 in log phase stage in the modified Postgate B medium containing $1 \% \mathrm{NaCl}$.

\subsection{Isolation}

SRB sample taken from well No.3 of Bach Ho field was cultivated in $1 \% \mathrm{NaCl}$ modified Postgate B containing $1 \%$ crude oil at $30^{\circ} \mathrm{C}$ under anaerobic condition. The sample was then inoculated on $1 \% \mathrm{NaCl}$ modified Postgate $\mathrm{B}$ agar medium containing $1 \%$ crude oil at $30^{\circ} \mathrm{C}$ under anaerobic condition for isolation the strain D107G3.

\subsection{Gram staining}

The mesophilic sulfate reducing bacterial strain D107G3 was grown in $1 \% \mathrm{NaCl}$ modified Postgate $\mathrm{B}$ medium at $30^{\circ} \mathrm{C}$ under anaerobic condition. After 24 hours of incubation, bacterial sample was taken and made Gram staining, and the Gram staining sample of strain D107G3 was observed on the optical microscopy to determine Gram type.

\subsection{Scanning electron microscope (SEM) observation}

The mesophilic sulfate reducing bacterial strain D107G3 was cultivated in $1 \% \mathrm{NaCl}$ modified Postgate B medium at $30^{\circ} \mathrm{C}$ under anaerobic condition. This strain was then transferred to $1 \% \mathrm{NaCl}$ Postgate $\mathrm{B}$ medium modified containing $1 \%$ crude oil as a substrate source. When the strain D107G3 grow well, its culture was filtered to remove the FeS residues, then the cell culture was centrifuged $8000 \mathrm{rpm}$ at $4^{\circ} \mathrm{C}$ for 10 minutes, and after that the cell pellet was rinsed with PBS ( $\mathrm{pH}=7.2)$. Sample preparation and cell shape observation by the scanning electron microscope HITACHI $\$ 4800$ according to Pham and Lai (2010).

\subsection{S rRNA gene sequence analysis}

The strain D107G3 was pre-cultivated in 1\% NaCl modified Postgate B medium. This strain was then incubated on Postgate $\mathrm{C}$ medium containing $1 \% \mathrm{NaCl}$ for 4 days at $30^{\circ} \mathrm{C}$. The FeS residues were filtered out and then the cell suspension was centrifuged to $8000 \mathrm{rpm}$ at $4^{\circ} \mathrm{C}$ for 10 minutes to collect cells. The total DNA of this strain was extracted using a bacterial DNA extraction kit (Qiagen, USA). Total DNA quality was tested on $1 \%$ agarose gel. The next steps were considered as PCR amplification, PCR product purification, gene sequences, sequence analysis, phylogenetic tree construction, which have been mentioned in Sakiyama et al. (2009).

\subsection{Examination of the effects of environmental factors on the growth of strain D107G3 in medium containing crude oil as a sole carbon source}

The effects of crude oil content, temperature, $\mathrm{NaCl}$ salt concentration and $\mathrm{pH}$ on the growth of mesophilic sulfate reducing bacterial strain D107G3 under anaerobic conditions were performed sequentially. The strain D107G3 was pre-cultivated in the modified Postgate B medium $1 \% \mathrm{NaCl}$. Then, it were cultivated in the $1 \% \mathrm{NaCl}$ modified Postgate B media with variant crude oil concentration (experiment on the effect of crude oil content-exp.1), temperature (experiment on the effect of temperature with the most suitable crude oil concentration that was determined in exp.1-exp.2), NaCl concentration (experiment on the effect of $\mathrm{NaCl}$ 
concentration basing on the most suitable crude oil concentration, temperature that were determined in exp.1, exp.2, -exp3), pH (experiment on the effect of $\mathrm{pH}$ under condition of the most suitable crude oil concentrations, temperature, $\mathrm{NaCl}$ concentration that were determined at exp.1, exp.2, exp.3-exp.4). The growth of the strain D107G3 under these different conditions was evaluated through the amount of its produced $\mathrm{H}_{2} \mathrm{~S}$ (determined by iodometric titration).

\subsection{Analysis of total oil content and crude oil composition utilized by the strain D107G3}

The mesophilic sulfate reducing bacterial strain D107G3 was pre-cultivated in $1 \% \mathrm{NaCl}$ modified Postgate $\mathrm{B}$ medium. Then, the strain anaerobically was cultivated in the modified Postgate $\mathrm{B}$ medium containing the most suitable crude oil, $\mathrm{NaCl}$ concentration that were determined by exp.1, exp.3 and under the most appropriate temperature and $\mathrm{pH}$ that were determined by exp.2, exp.4. After 4 weeks of incubation, the total oil content and crude oil component utilized by the strain D107G3 were determined by oil-in-water separation method and gas chromatographic method, respectively (Nguyen et al., 2011).

\section{Results and discussion}

\subsection{Morphology of the mesophilic sulfate reducing bacterial strain D107G3}

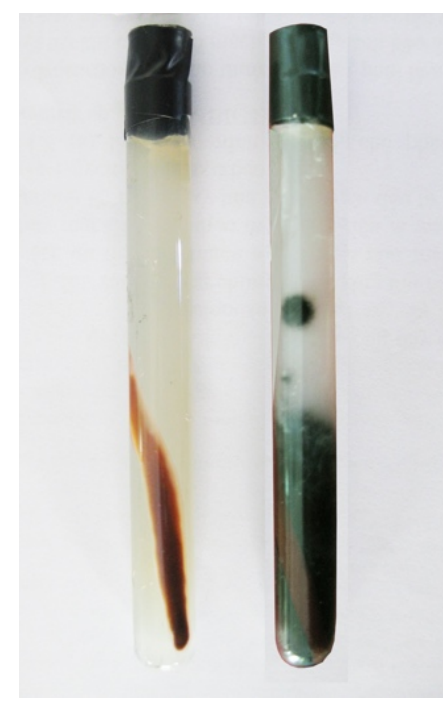

(a)

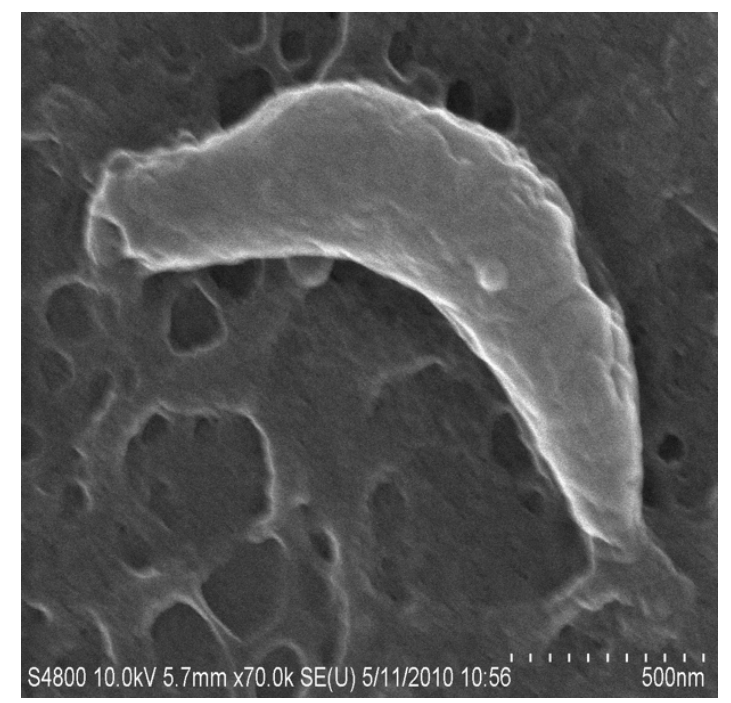

(b)

Figure 1. Colony morphology (a-left: $1 \% \mathrm{NaCl}$ modified Postgate $\mathrm{B}$ agar medium containing $1 \%$ crude oil, a-right: D107 strain grew in $1 \% \mathrm{NaCl}$ modified Postgate $\mathrm{B}$ agar medium containing $1 \%$ crude oil) and cell morphology (b) of the strain D107G3 in the modified Postgate B medium containing $1 \%$ crude oil.

The results which have been reported by Nguyen et al (2010) showed that there were several SRB communities taken from Vung Tau gas-oil field that were capable of using crude oil as a substrate source, including the mesophilic SRB communities taken from D107G3 well. In order to found out more the physiology, a single strain could be isolated. The colony morphology of strain D107G3 on $1 \% \mathrm{NaCl}$ modified Postgate B agar containing $1 \%$ crude oil was shown in Figure 1a. SEM observation of the cell morphology pointed out that the cell of strain D107G3 has a curved rod shape (Figure 1b) that is the typical shape of SRB (Muyzer, Stams, 2008). Gram staining results figured out that the strain D107G3 is Gramnegative bacterium. This result is in agreement with the domestic and foreign studies that most of the mesophilic SRB are Gram-negative bacteria (Lai Thuy Hien, Dang
Phuong Nga, 1998; Lai el al., 2003; Pikuta et al., 2003; Muyzer and Stams, 2008; Nguyen et al., 2011).

\subsection{Identification of the mesophilic sulfate reducing bacterial strain $\mathrm{D} 107 \mathrm{G} 3$}

In order to figure out more the classification of a mesophilic sulfate reducing bacterial strain D107G3, its $16 S$ rRNA gene sequence was analysed. Its phylogenetic tree was presented in Figure 2. It showed that the strain D107G3 had $99.7 \%$ similarity with Desulfovibrio vulgaris. This result is in the agreement with Brooijmans et al. (2009) and Nasser et al. (2017) that Desulfovibrio vulgaris is a hydrocarbon-degrading bacterium. 


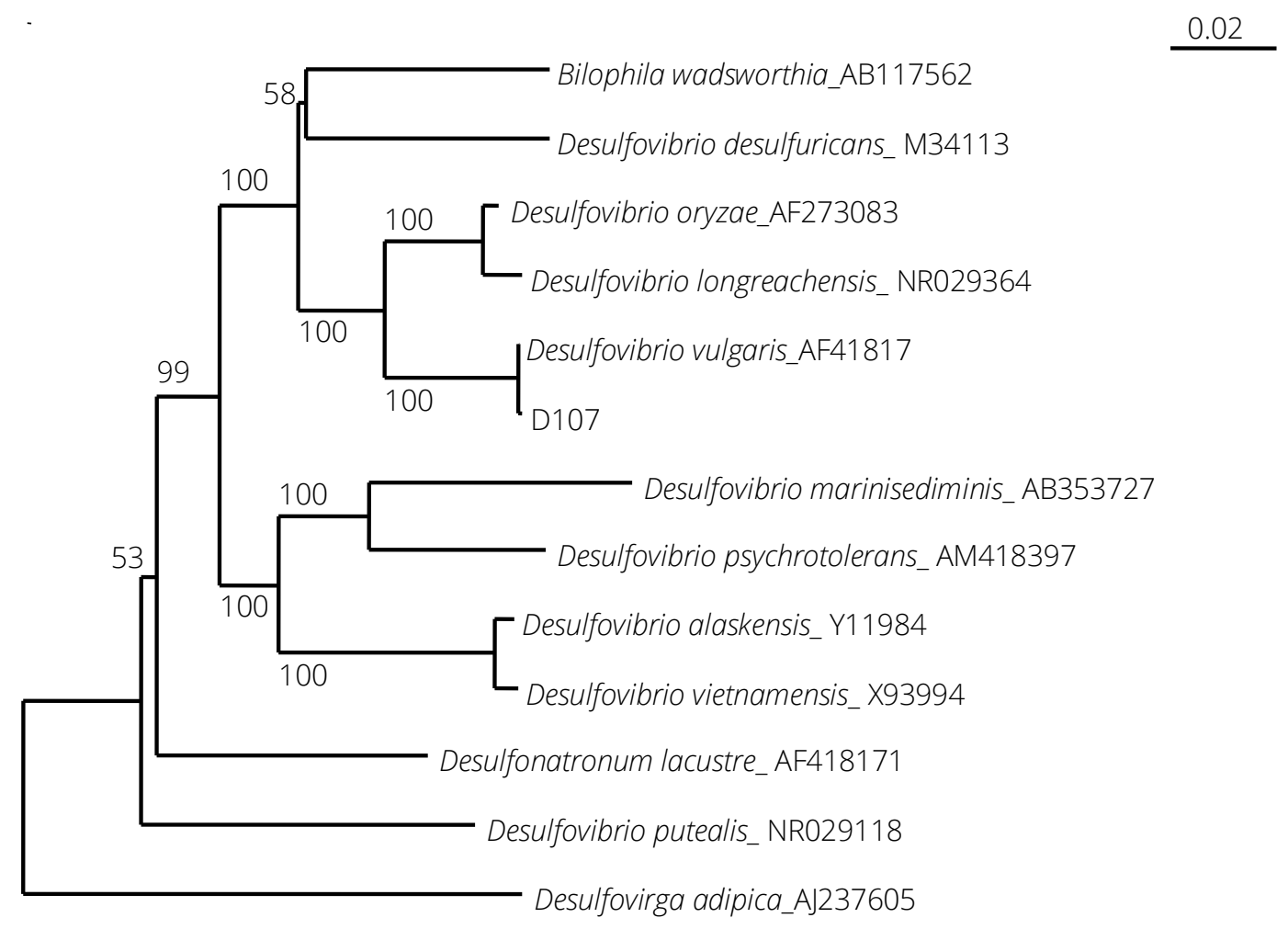

Figure 2. Phylogenetic tree based on 16S rRNA sequence of a bacterial strain D107G3 and related species

\subsection{Effects of environmental factors on the growth of strain D107G3 in the medium containing crude oil}

To determine what is the suitable condition for the growth of bacteria strain D107G3 when it utilized the crude oil as a carbon source, the experiments for investigation of the effects of environmental factors including crude oil concentration, temperature, $\mathrm{NaCl}$ concentration and $\mathrm{pH}$ were performed one by one. Results are shown in Figure 3.

The Figure 3a showed that the strain D107G3 had a high ability to utilize crude oil. It was capable of growing on crude oil from $0.5 \%$ to $20 \%$. However, it could not grow when the concentration of crude oil reached to 30\% in medium. In the medium containing 1\% crude oil, the D107G3 strain grew best (Figure 3a). Various studies had shown that the suitable crude oil concentration for SRB growth is from $0.5 \%$ to $5 \%$ (Kniemeyer et al., 2003; Nakagawa et al., 2008; Nguyen et al., 2011). Therefore, the results of this study confirm once again the range of crude oil concentration for SRB's suitable growth. Results on the effect of temperature on the growth of strain D107G3 (Figure $3 \mathrm{~b}$ ) showed that this strain could not grow at $4^{\circ} \mathrm{C}$ and $55^{\circ} \mathrm{C}$, grew well at the temperature $30^{\circ} \mathrm{C}$ and $37^{\circ} \mathrm{C}$ and its optimal growth was $30^{\circ} \mathrm{C}$ (the amount of produced $\mathrm{H}_{2} \mathrm{~S}$ was higher at $30^{\circ} \mathrm{C}$ than at $37^{\circ} \mathrm{C}$ - data not shown). This result is agreement with the growth temperature range of the mesophilic SRB (Davidova et al., 2006; Cravo-Laureau et al., 2007; Nguyen et al., 2011).

The results of the effect of $\mathrm{NaCl}$ concentration on the growth of strain D107G3 (Figure 3c) showed that the strain D107G3 was able to grow in the range from $0 \% \mathrm{NaCl}$ to $5 \%$ $\mathrm{NaCl}$. Its growth ability was reduced when the $\mathrm{NaCl}$ concentration was up to $10 \%, 20 \%$. It could not grow in medium containing $30 \% \mathrm{NaCl}$. The most suitable for its growth was a medium containing $1 \% \mathrm{NaCl}$. This finding is so interesting since the normal concentration of $\mathrm{NaCl}$ in the seawater in Vung Tau is 2-3\%. This strain is separated from a secondary exploitation well by pumping seawater. Thus, a 2-3\% NaCl concentration is generally considered to be the suitable concentration for its growth. However, our results implied that its preferred $\mathrm{NaCl}$ concentration for the growth is 1\%. Therefore, further studies are needed to find out the origin of this strain D107G3.

The results (Figure 3d) showed that the strain D107G3 was capable of growing in the $\mathrm{pH}$ range of $5-9$ and the neutral $\mathrm{pH}(\mathrm{pH}=7)$ was the optimal $\mathrm{pH}$ for the growth of this strain. This result once again confirmed the $\mathrm{pH}$ range suitable for the growth of the general mesophilic SRB (Feio et al., 2004; Cravo-Laureau et al., 2004; 2007) as well as mesophilic SRB isolate from Vung Tau gas oil wells (Dang et al., 1996; Lai Thuy Hien, Dang Phuong Nga, 1998; Nguyen et al., 2011). In sum, the most suitable medium for the growth of a strain D107G3 is the medium containing 1\% crude oil, 1\% NaCl, $\mathrm{pH} 7$ and the incubation condition at $30^{\circ} \mathrm{C}$. 


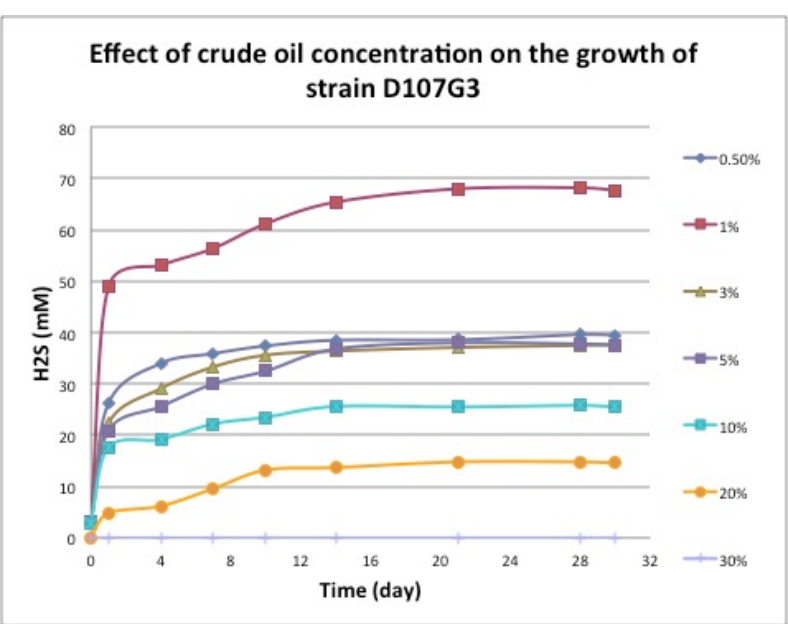

a

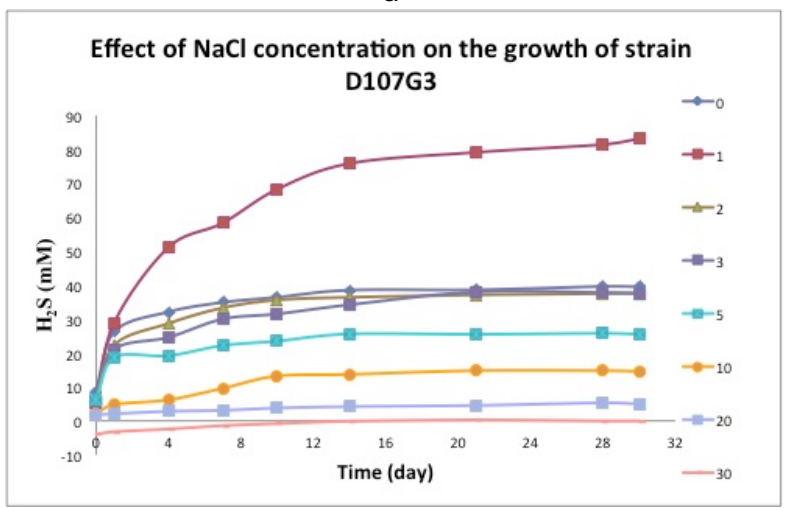

C

\begin{tabular}{|c|c|c|c|c|}
\hline \multirow{2}{*}{ Strain } & \multicolumn{4}{|c|}{ Temperature $\left({ }^{\circ} \mathrm{C}\right)$} \\
\cline { 2 - 5 } & 4 & 30 & 37 & 55 \\
\hline D107G3 & -+ & +++ & ++ & -+ \\
\hline
\end{tabular}

Notes: +++ : very good growth; ++ : good growth ; -+ : weak growth; -: no growth

b

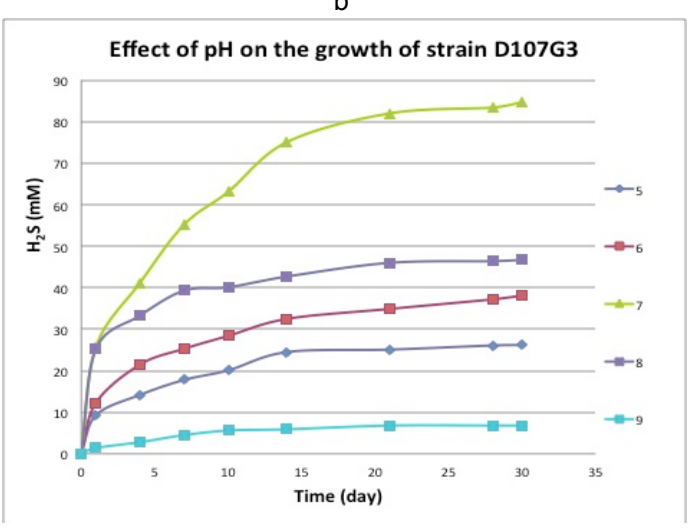

d

Figure 3. Effect of the crude oil concentration (\% v/v) (a), temperature (b), concentration of $\mathrm{NaCl}(\%)(c)$ and pH (d) on the growth of the strain D107G3

\subsection{Evaluation of total oil content and composition utilized by the strain D107G3}

The strain D107G3 was anaerobically cultured in the suitable medium modified Postgate B containing 1\% crude oil, $1 \% \mathrm{NaCl}, \mathrm{pH} 7$ and the incubation condition at $30^{\circ} \mathrm{C}$. After 30 days of incubation, oil content and composition utilized by this strain was analyzed by oil-in-water separation method and gas chromatographic method, respectively. Basing on the oil-in-water separation method, it was shown that the crude oil content utilized by the strain D107G3 was $11.4 \%$. The result of analysis of oil content of the control sample and the strain D107G3 sample showed that the strain D107G3 had higher nparaffin content (especially from nC10 to nC28) than the control sample (Figure 4). This implied that this strain might utilize crude oil components with long chain hydrocarbon $C \geq 45$. As a result, the crude oil could be more liquid. Therefore, this strain can be used in the treatment of heavy hydrocarbon fractions ( $\mathrm{C} \geq 45)$ after exploitation.

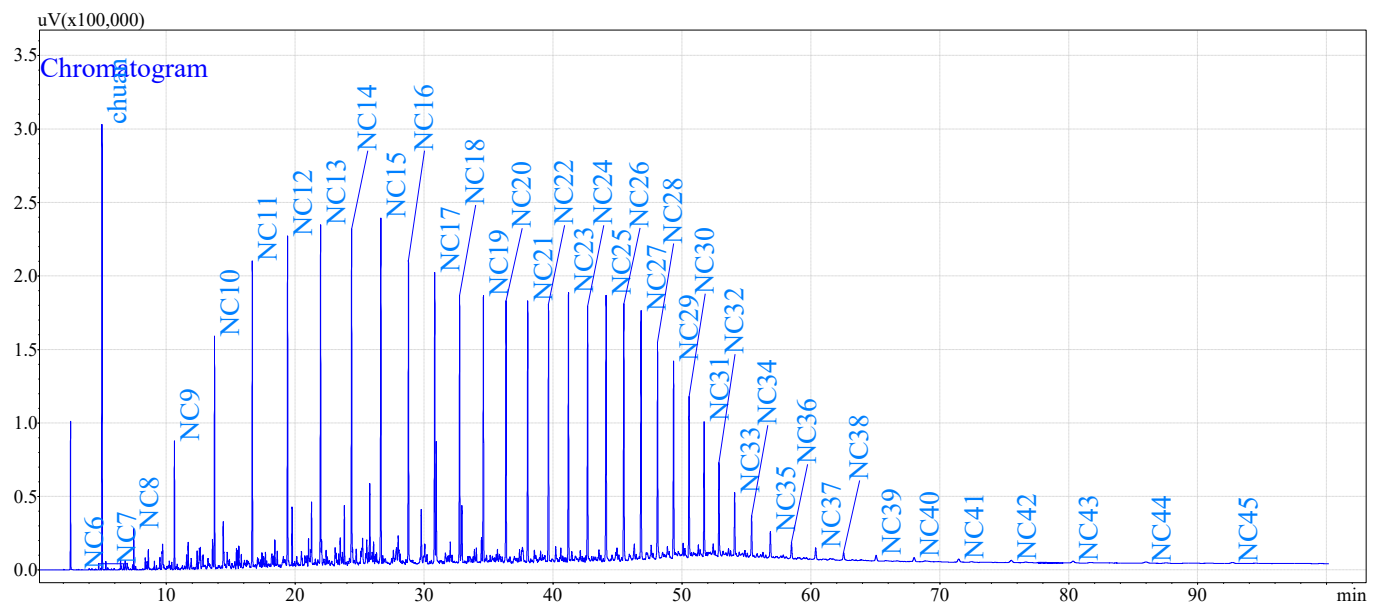

a 


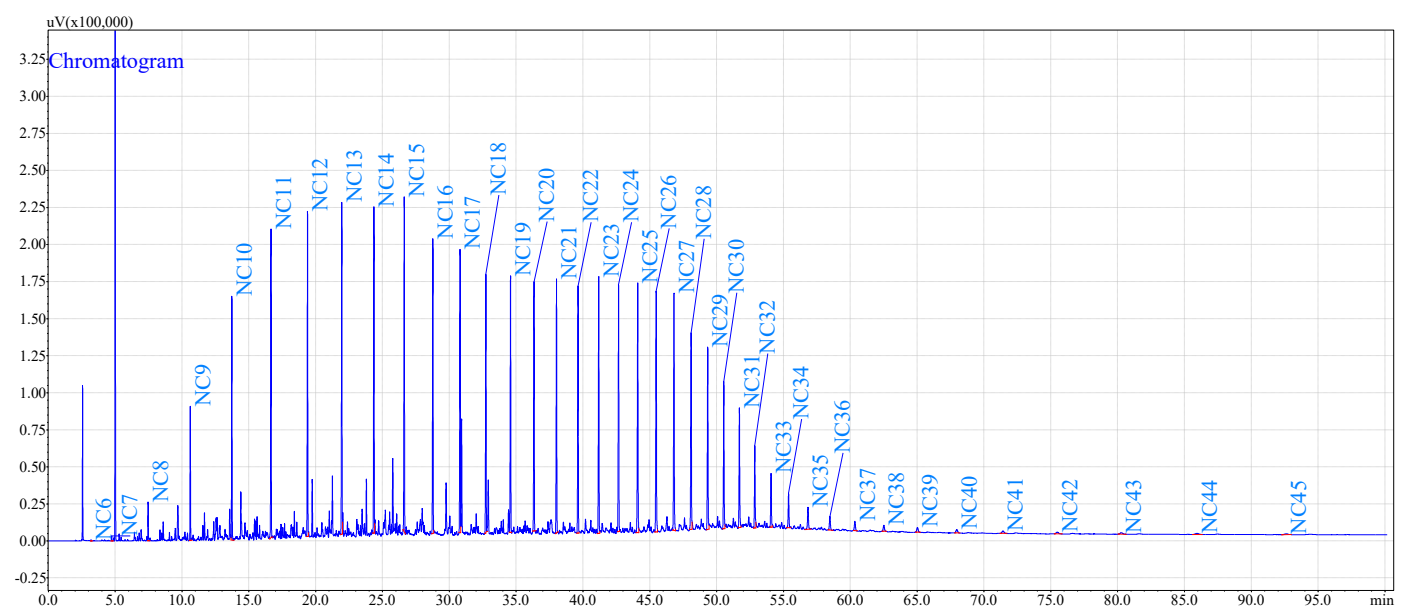

b

Figure 4. Gas chromatogram of control sample (a) and the strain D107G3 after 30 days of incubation in suitable conditions for its growth.

\section{Conclusion}

The mesophilic sulfate reducing bacterial strain D107G3 isolated from the Bach Ho gas oil field, Vung Tau was a Gram-negative bacterium with curved rod shape. The $16 \mathrm{~S}$ rRNA gene sequence analysis showed that this strain belonged to Desulfovibrio vulgaris (99.7\% homogeneity). The strain D107G3 is best grown in the modified Postgate B medium containing 1\% (v/v) crude oil, 1\% NaCl ( $\left.\mathrm{gL}^{-1}\right), \mathrm{pH}$ 7 and incubation at $30^{\circ} \mathrm{C}$. This strain utilized $11.4 \%$ of the total crude oil content and the decomposed oil components were n-paraffins of length $C \geq 45$ after 30 days incubation under anaerobic conditions in the most suitable conditions for its growth.

\section{Acknowledgments}

The authors thanks to the Institute of Scientific Research and Development, Vietsopetro Vung Tau Petroleum Exploitation Enterprise; National Institute of Hygiene and Epidemiology; Institute of Microbiology and Biotechnology, Hanoi National University for the nice cooperation.

\section{References}

[1] Al- Asadi, A. A. B (2011). Anaerobic degradation of crude oil by sulfate reducing bacteria isolated from soils contaminated with petroleum hydrocarbons. J. Thi-Qar Sci., 2(4), 3-12.

[2] Basafa, M., Hawboldt, K. (2018). Reservoir souring: sulfur chemistry in offshore oil and gas reservoir fluids. Petroleum Exploration and Production Technology, 9, 1105-1118. https://doi.org/10.1007/ s13202-018-0528-2

[3] Brooijmans, R. J. W., Pastink, M. I., Siezen, R. J. (2009) Hydrocarbon-degrading bacteria: the oil-spill cleanup crew. Microbial Biotechnology, 2(6), 587-594. https://doi.org/10.1111/j.1751-7915.2009.00151.x.
[4] Cravo-Laureau, C., Labat, C., Joulian, C., Matheron, R., Hirschler-Réa, A., (2007). Desulfatiferula olefinivorans gen. nov., sp. nov., a long-chain n-alkene-degrading, sulfate-reducing bacterium. Systematic and Evolutionary Microbiology, 57(11), 2699-2702. https://doi.org/10.1099/ijs.0.65240-0.

[5] Cravo-Laureau, C., Matheron, R., Cayol, J. L., Joulian, C., Hirschler-Réa, A. (2004). Desulfatibacillum aliphaticivorans gen. nov., sp. nov., an n-alkane- and n-alkene-degrading, sulfate-reducing bacterium. Systematic and Evolutionary Microbiology, 54, 77-83. https://doi.org/10.1099/ijs.0.02717-0.

[6] Dang, P. N., Dang, T. C. H., Lai, T. H., Sta-Lotter, H., (1996). Desulfovibrio vietnamensis sp. nov., a halophilic sulfate-reducing bacterium from Vietnamese oil field. Anaerobe, 2, 385-392. https://doi.org/10.1006/ anae.1996.0049.

[7] Davidova, I. A., Duncan, K. E., Choi, O. K., Suflita, J. M., (2006). Desulfog/aeba alkanexedens gen. nov., sp. nov., an n-alkane-degrading, sulfate-reducing bacterium. Systematic and Evolutionary Microbiology, 56, 2737 2742. https://doi.org/10.1099/ijs.0.64398-0.

[8] Enning D., Garrelfs J. (2014). Corrosion of Iron by Sulfate-Reducing Bacteria: New Views of an Old Problem. Applied and Environmental Microbiology, 80(4), 1226-1236. https://doi.org/10.1128/AEM. 02848-13.

[9] Feio, M. J., Zinkevich, V., Beech, I. B. Llobet-Brossa, E., Eaton, P., Schmitt, J., Guezennec, J. (2004). Desulfovibrio alaskensis sp. nov., a sulphate-reducing bacterium from a soured oil reservoir. Systematic and Evolutionary Microbiology, 54, 1747-1752. https://doi.org/10.1099/ijs.0.63118-0.

[10] Jaekel, U., Johannes, Z. J., Wilkes, H., Musat, F. (2015) Anaerobic degradation of cyclohexane by sulfatereducing bacteria from hydrocarbon contaminated marine sediments. Microbiology, 6, https://doi.org/ 
10.3389/fmicb.2015.00116.

[11] Kniemeyer, O., Fischer, T., Wilkes, H., Glöckner, O. F., Widdel, F. (2003). Anaerobic Degradation of Ethylbenzene by a New Type of Marine SulfateReducing Bacterium. Applied and Environmental Microbiology, 69 (2), 760-768. https://doi.org/ 10.1128/AEM.69.2.760-768.2003.

[12] Pikuta, E. V., Hoover, R. B., Bej, A. K., Marsic, D., Whitman, W. B., Cleland, D., Krader, P. (2003). Desulfonatronum thiodismutans sp. nov., a novel alkaliphilic, sulfate-reducing bacterium capable of lithoautotrophic growth. Systematic and Evolutionary Microbiology, 53, 1327-1332. https:// doi.org/10.1099/ijs.0.02598-0.

[13] Lai, T. H., Dang, P. N. (1998). Physiological and biochemical properties of some sulfate-reducing bacterial strains isolated from Bach Ho gas-oil wells. Biology, 20(2), 33-38.

[14] Lai, T. H., Nguyen, T. T. H., Do, T. P., Vu, P. A., Kieu, H. A. (2003). Physiological and biochemical properties of some thermophilic sulfate-reducing bacteria isolated from Vung Tau gas-oil wells. Science and Technology, 41(4), 1-7.

[15] Lai, T. H., Do, T. P., Le, P. N., Dang, P. N., Pham, T. T., Hoang, H., Pham, T. H. (2000). Microflora in Vung Tau gas oil filed and application of useful microorganism. National Conference of Biology, 77-83.

[16] Muyzer, G., \& Stam, A. J. M. (2008). The ecology and biotechnology of sulphate-reducing bacteria. Nature Reviews Microbiology, 6(6), 441-454. https://doi.org/10.1038/nrmicro1892.

[17] Nakagawa, T., Sato, S., Fuku, M. (2008). Anaerobic degradation of p-xylene in sediment-free sulfatereducing enrichment culture. Biodegradation, 19, 909-913. https://doi.org/10.1007/s10532-008-91924.

[18] Nasser, B., Ramadan, A. R., Hamzah, R. Y., Mohamed, M. E., Ismail, W. A. (2017). Detection and Quantification of Sulfate-Reducing and Polycyclic Aromatic Hydrocarbon-Degrading Bacteria in Oilfield Using Functional Markers and Quantitative PCR. Petroleum and Environmental Biotechnology, 8, https://doi.org/10.4172/2157-7463.1000348.
[19] Nguyen, T. T. H., Trương, D. D., Lai, T. H. (2010). Study on the cride oil utilizing capacity of sulfate reducing bacteria isolated from Vung Tau gas oil field. Scientific Conference celebrates the 35th anniversary of Vietnam Academy of Science and Technology 19752010, Subcommittee of Life Science, 208-218.

[20] Nguyen T. T. H., Trương D. D., Lai T. H. (2011) Mesophilic crude oil utilizing sulfate-reducing bacterium Desulfovibrio desulfuricans DH3P isolated form Dai Hung gas-oil well, Vung Tau. Marine Science and Technology, 11(4), 21-33. https://doi.org/ 10.15625/jmst.v11i4.383.

[21] Pham, T. H., Lai, T. H. (2010). Study on bacterium Dietzia sp. A343.4 isolated form JetA1 and its effect on JetA1 quality. Biotechnology, 8(3A), 853-863.

[22] Rabus, R., Boll, M., Heider, J., Meckenstock, R. U., Buckel, W., Einsle, O., Ermler, U., Golding, B. T., Gunsalus, R. P., Kroneck, P. M. H., Krüger, M., Lueders, T., Martins, B. M., Musat, F., Richnow, H. H., Schink, B., Seifert, J., Szaleniec, M., Tina, T. T., Ullmann, G. M., Vogt, C., von Bergen, M., Wilkes, H. (2016). Anaerobic Microbial Degradation of Hydrocarbons: From Enzymatic Reactions to the Environment. Molecular Microbiological Biotechnology, 26, 5-28. https://doi.org/10.1159/000443997.

[23] Roy, A., Sar, P., Sarkar, J., Dutta, A., Sarkar, P., Gupta, A., Mohapatra, B., Pal, S., Kazy, S. K. (2018). Petroleum hydrocarbon rich oil refinery sludge of North-East India harbours anaerobic, fermentative, sulfatereducing, syntrophic and methanogenic microbial populations. BMC Microbiology, 18, https://doi.org/ 10.1186/s12866-018-1275-8.

[24] Sakiyama, Y., Nguyen, K. N. T., Nguyen, M. G., Miyadoh, S., Duong, V. H., Ando, K. (2009). Kineosporia babensis sp. nov., isolated from plant litter in Vietnam. Systematic and Evolutionary Microbiology, 59, 550554. https://doi.org/10.1099/ijs.0.002907-0.

[25] Suárez-Suárez, A., López-López, A., Tovar-Sánchez, A., Yarza, P., Orfila, A., Terrados, J., Arnds, J., Marqués, S., Niemann, H., Schmitt-Kopplin, P., Amann, R., RossellóMóra, R. (2011). Response of sulfate-reducing bacteria to an artificial oil-spill in a coastal marine sediment. Environmental Microbiology, 13(6), 14881499. https://doi.org/10.1111/j.1462-2920.2011. 02451.x. 